\title{
The Renin-Angiotensin System Modulates Inflammatory Processes in Atherosclerosis: Evidence from Basic Research and Clinical Studies
}

\author{
Fabrizio Montecucco, ${ }^{1}$ Aldo Pende, ${ }^{2}$ and François Mach $^{1}$ \\ ${ }^{1}$ Division of Cardiology, Foundation for Medical Researches, University Hospital of Geneva, 64 Avenue Roseraie, \\ 1211 Geneva, Switzerland \\ ${ }^{2}$ Clinic of Internal Medicine I, Department of Internal Medicine, University of Genoa 16132, Genoa, Italy
}

Correspondence should be addressed to Fabrizio Montecucco, fabrizio.montecucco@medecine.unige.ch

Received 22 October 2008; Revised 7 January 2009; Accepted 29 January 2009

Recommended by Philipp M. Lepper

Recent evidence shows that the renin-angiotensin system is a crucial player in atherosclerotic processes. The regulation of arterial blood pressure was considered from its first description of the main mechanism involved. Vasoconstriction (mediated by angiotensin II) and salt and water retention (mainly due to aldosterone) were classically considered as pivotal proatherosclerotic activities. However, basic research and animal studies strongly support angiotensin II as a proinflammatory mediator, which directly induces atherosclerotic plaque development and heart remodeling. Furthermore, angiotensin II induces proatherosclerotic cytokine and chemokine secretion and increases endothelial dysfunction. Accordingly, the pharmacological inhibition of the reninangiotensin system improves prognosis of patients with cardiovascular disease even in settings of normal baseline blood pressure. In the present review, we focused on angiotensin-convertingenzyme (ACE) inhibitors, angiotensin II receptor blockers (ARBs), and renin inhibitors to update the direct activities of the renin-angiotensin system in inflammatory processes governing atherosclerosis.

Copyright ( 2009 Fabrizio Montecucco et al. This is an open access article distributed under the Creative Commons Attribution License, which permits unrestricted use, distribution, and reproduction in any medium, provided the original work is properly cited.

\section{Introduction}

Atherosclerosis is a chronic inflammatory disease, which involves vascular cells, immune system, and several organs [1]. Although leukocytes, endothelial and smooth muscle cells have been shown to play a crucial role in atherosclerotic inflammation, recent evidence also supports a direct activity for the liver, lung, heart, kidney, adipose tissue, adrenal, pancreatic, pituitary, and sex glands [2]. These organs produce several soluble inflammatory mediators, which orchestrate vascular and immune cell functions. Although cytokines, chemokines as well as growth factors have been shown to modulate inflammatory processes, recent studies suggest new inflammatory activities for endocrine hormones [3, 4]. The renin-angiotensin system could serve an important role in promoting inflammation $[4,5]$. However, despite its first description by Tigerstedt and Bergman over a century ago [6], the role of these hormones in inflammatory processes is still unclear. The recent identification of new angiotensins and the different roles of angiotensin and renin/prorenin receptors increased the complexity of this system, suggesting that further investigations are needed to better understand the role of renin-angiotensin axis in inflammation (Figure 1) [7-9]. Furthermore, the description of the angiotensin-converting enzyme (ACE) 2 and its main product (angiotensin ${ }^{1-7}$ ) raised some controversies $[10,11]$. ACE 2 and angiotensin ${ }^{1-7}$ levels are not influenced by ACE inhibitors or angiotensin II receptor blockers (ARBs). On the other hand, the "negative feed-back" regulating plasma renin activity is modulated by these drugs [12] (Figure 2). ACE 2 and angiotensin ${ }^{1-7}$ rather appear to be upregulated by these drugs maily in the myocardium and kidney $[13,14]$. ACE 2 is also highly expressed in hypothalamus and aorta, and it is considered as a possible modulator of the renin-angiotensin system [15]. In particular, both ACE 2 and angiotensin ${ }^{1-7}$ may counterbalance excess of activity of the "classical" renin-angiotensin system (Figure 3). Angiontenin II has been detected also in peripheral tissues (such as aortic tissue), 


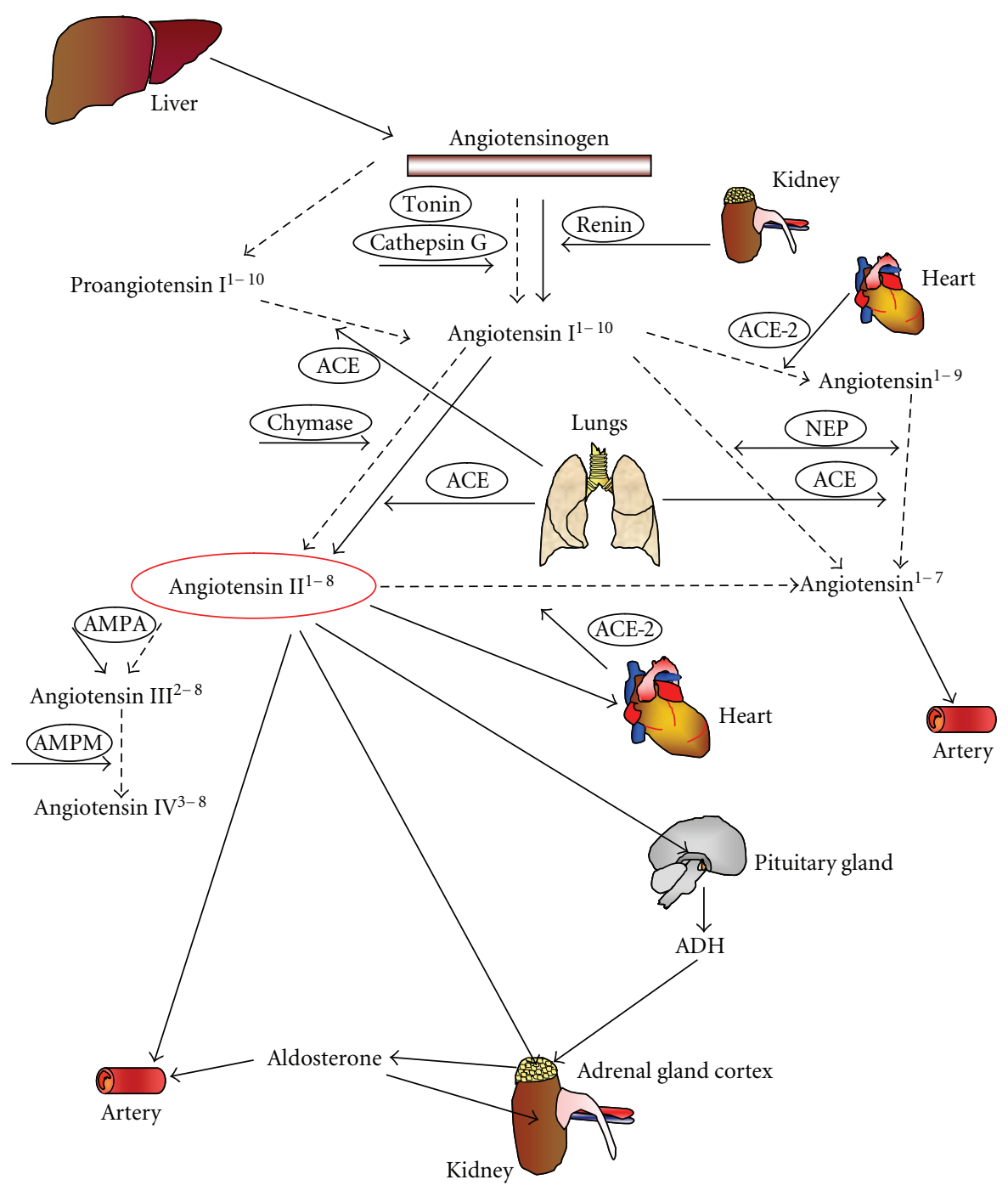

FIGURE 1: Expanded renin-angiotensin-aldosteron system. Recently, the identification of new angiotensins with different activities increased the complexity of this hormonal axis. In addition to the crucial activities of the liver, kidney, lung, adrenal gland cortex, and pituitary gland, the heart also influences this system. ACE: angiotensin converting enzyme; ACE-2: angiotensin converting enzyme 2; NEP: neutral endopaptidase; AMPA: aminopeptidase A; AMPM: aminopaptidase M.

suggesting a possible role of the local renin-angiotensin system in atherosclerosis [16]. Both local and circulating angiotensin II exert their activities through the binding to angiotensin II type $1\left(\mathrm{AT}_{1}\right)$ or type $2\left(\mathrm{AT}_{2}\right)$ receptors. $\mathrm{AT}_{1}$ receptor is widely expressed on different cell types involved in atherosclerogenesis [17]. $\mathrm{AT}_{2}$ receptors are ubiquitously expressed in foetus and dramatically fall in the first few hours after birth [18]. Recently, a local renin-angiotensin system characterized by the expression of both $\mathrm{AT}_{1}$ and $\mathrm{AT}_{2}$ receptors has been also shown in adipose tissue [19]. Furthermore, the rediscovery of the "intracellular" activity of angiotensin II as a major factor involved in cardiac remodeling suggested new possible investigation fields [20-22]. The present review will be focused on evidences from basic research studies and clinical trials, investigating the role of the "revisited" reninangiotensin system [7] and its pharmacological inhibitions in atherosclerotic inflammatory processes (Figure 2).

\section{ACE Inhibitors, ARBs, and Renin Inhibitors in Atherosclerotic Inflammatory Processes: Basic Research and Animal Studies}

In the last decades, basic researches have strongly suggested that the renin-angiotensin system blockade exerts potent antiatherosclerotic effects, not only through the antihypertensive pathway but also through anti-inflammatory, antiproliferative, and antioxidant properties [23]. Among these hormones, angiotensin II is considered as the main proatherosclerotic mediator. Angiotensin II regulates not only adhesion molecule (VCAM-1, ICAM-1, P-selectin) expression but also cytokine, chemokine, and growth factor secretion within the arterial wall [24]. On the other hand, the renin-angiotensin system can modulate the activation of complement system in both atherosclerosis and renal injury [25-27]. This inflammatory cascade activates the 


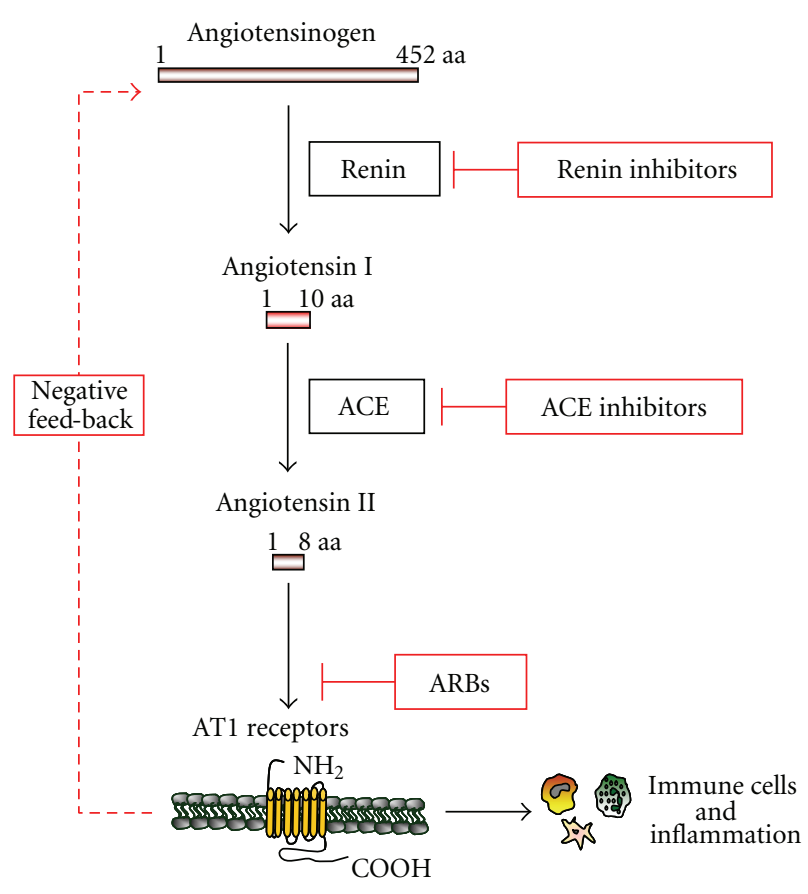

FIGURE 2: Simplified view of renin-angiotensin pathway and its pharmacological inhibition. Renin inhibitors, ACE inhibitors, and $\mathrm{ARB}$ modulate angiotensin activities in inflammatory processes. $\mathrm{AT}_{1}$ receptors, which are expressed in immune cells, have been shown to trigger inflammatory pathways.

vascular inflammatory response by increasing inflammatory cell recruitment to intima. Recruited cells can produce angiotensin II (intracellular angiotensin system), resulting in a positive feedback response, which can maintain this inflammatory vicious circle. In humans, an analysis of both ruptured and hypercellular plaques demonstrated high levels of ACE in macrophages. Accordingly, little or no ACE was found in areas with only fibrotic plaques $[28,29]$. These data suggest that ACE may be associated to atherosclerotic plaque development and vulnerability through the direct regulation of inflammatory cells. Furthermore, angiotensin II favors the intraplaque recruitment of monocytes and lymphocytes [30] and directly enhances TNF- $\alpha$, IL- 6 and cyclooxygenase2 expression in atherosclerotic arteries [31]. Angiotensin IImediated effect could be potentitated by C-reactive protein (CRP) through the upregulation of $\mathrm{AT}_{1}$ receptor expression in vascular smooth muscle cells [32]. Angiotensin II has been also shown to increase LDL oxidation in macrophages $[33,34]$, oxLDL receptor (LOX-1) expression in endothelial cells [35], superoxide and metalloproteinase production, and lipid peroxidation [36]. In addition, the inactivation of nitric oxide $(\mathrm{NO})$ and prostacyclin $\left(\mathrm{PGI}_{2}\right)$ has been also observed in the presence of angiotensin II [37-40]. The binding between angiotensin II and $\mathrm{AT}_{1}$ receptor induced proinflammatory effect mainly through the down-stream activation of intracellular signaling cascade, which involves nuclear factorkappaB (NF- $\kappa$ B) activation [41-43]. The activation of NF$\kappa \mathrm{B}$ pathway increases hypertension-induced renal damage [44]. However, Henke et al. clearly showed that, despite the development of high blood pressure, in vivo NF- $\kappa$ B pathway suppression in endothelial cells reduced hypertensioninduced renal damage in mice with endothelial cell-restricted $\mathrm{NF}-\kappa \mathrm{B}$ superrepressor IkappaBalphaDeltaN overexpression [45]. Accordingly, the activation of NF- $\kappa \mathrm{B}$ pathways is also crucial in atherogenesis and macrophage activation/survival [46-48]. Therefore, angiotensin II through the activation of NF- $\kappa \mathrm{B}$ pathway could directly increase atherosclerotic inflammation. The majority of the direct proinflammatory effects induced by angiotensin II have been shown in studies with selective $\mathrm{AT}_{1}$ receptor blockers. Conversely, Kato et al. showed that renin-angiotensin system-activated transgenic mice receiving bone marrow transplantation from $\mathrm{AT}_{1} \mathrm{a}$ knockout (KO) mice. These transgenic animals displayed accelerated atherosclerosis and mortality [49]. The lethal effect was mainly mediated by $\mathrm{AT}_{1}$ a $\mathrm{KO}$ macrophages that overexpressed a number of genes involved in atherogenesis and exhibited a greater uptake of modified lipoproteins [49]. Given the controversial role of $\mathrm{AT}_{1}$ receptors, further investigations are needed. Less is known about $\mathrm{AT}_{2}$ receptors. They are mainly localized in cardiac interstitial fibroblasts and are capable of binding not only angiotensin II but also other angiotensins, including angiotensin III. $\mathrm{AT}_{2}$ receptors also signal through NF- $\kappa \mathrm{B}$-mediated pathways but they may counterbalance $\mathrm{AT}_{1}$ receptor-mediated effects through the activation of phosphatases rather than kinases [50-52]. $\mathrm{AT}_{2}$ receptor pathways increase bradykinin production and $\mathrm{NO}$ synthase activity in endothelial cells [50]. $\mathrm{AT}_{2}$ receptor activation also inhibits growth of cultured vascular smooth muscle cells and cardiac myocytes $[51,52]$. On the other hand, the selective $\mathrm{AT}_{2}$ receptor blockade has been shown to inhibit in vivo medial smooth muscle hypertrophy and fibrosis in hypertensive rats [51]. These controversial results suggest that also the role of $\mathrm{AT}_{2}$ receptors is still not clear. The renin-angiotenin system also influences inflammatory mediators involved in the coagulation cascade. In particular, this hormonal axis inhibits fibrinolysis and enhances thrombosis by increasing plasminogen activator-1 production in endothelial and vascular smooth muscle cells [53-55] and by activating platelets [56]. The renin-angiotensin system also stimulates platelets to release thromboxane A2 and platelet derived growth factor [54] and increases tissue factor levels in atherosclerotic plaques in acute coronary syndromes [57]. These basic research studies suggested that the pharmacological inhibition of the renin-angiotensin system may be of benefit against atherosclerotic inflammatory processes. In fact, ACE inhibitors or ARBs do not modulate exclusively kidney and arterial cell functions [58]. Inflammatory cell, adipocyte, and cardiomyocyte functions are directly regulated by these drugs [59-63]. Animal models partially confirmed these encouraging results. Two decades ago, the first preclinical studies in vivo showed that ACE inhibitors had not only blood-pressure-lowering properties [64] but also direct protective effects on endothelium and atherogenesis [65]. At an early stage of atherosclerosis, the treatment with different ACE inhibitors reduced endothelial dysfunction in atherogenic diet-fed [66] or hyperlipidemic rabbits [67]. Quinapril reduced macrophage infiltration in atherosclerotic lesions in femoral arteries in rabbits through the direct 


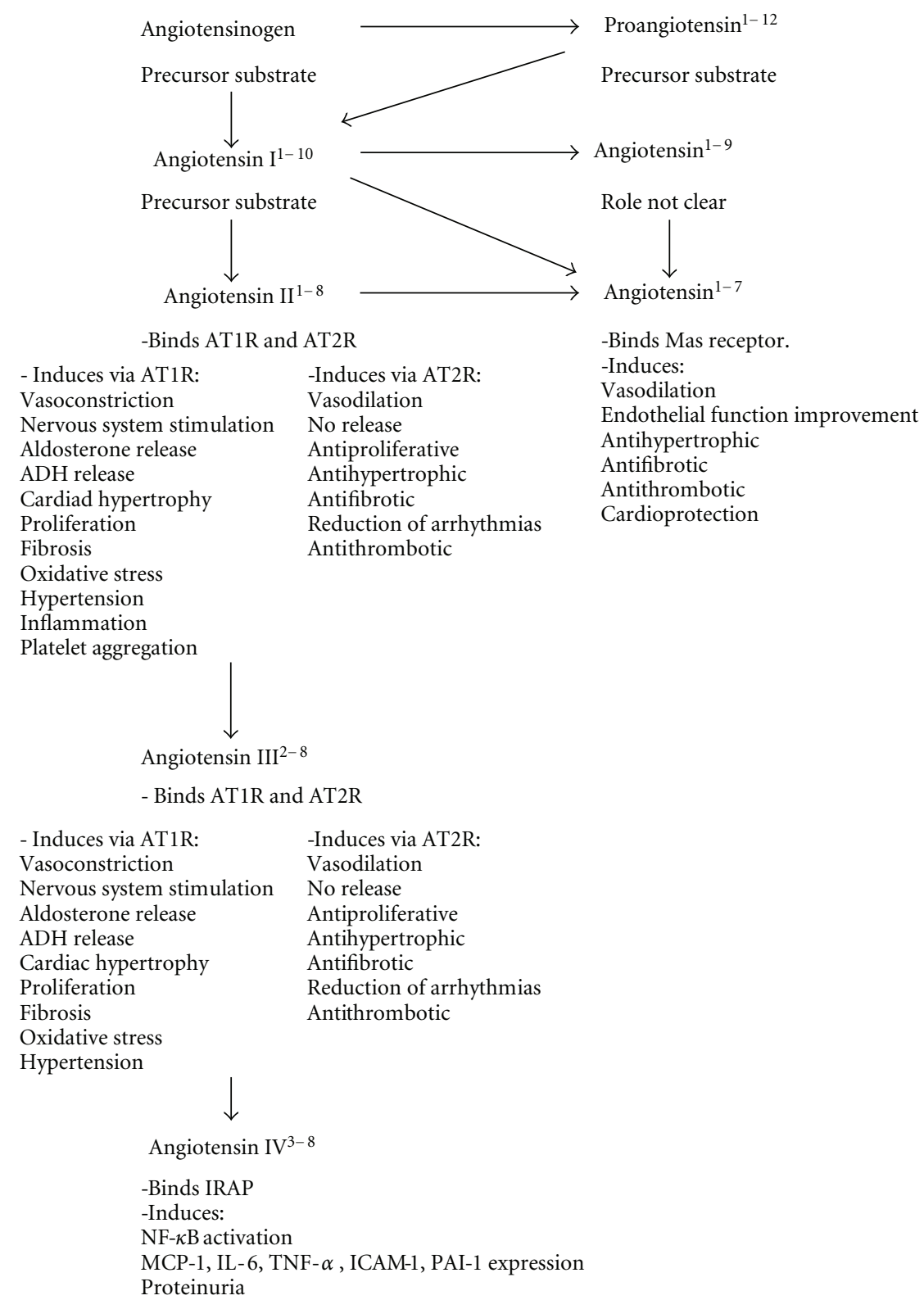

FIGURE 3: Revisited functions of the renin-angiotensin axis. Recent studies support that angiotensins influence several processes, including inflammation. $\mathrm{AT}_{1} \mathrm{R}$ : angiotensin type 1 receptor; $\mathrm{AT}_{2} \mathrm{R}$ : angiotensin type 2 receptor; IRAP: insulin-regulated aminopeptidase; Mas (mas oncogene) receptor.

inhibition of macrophage chemoattractant protein (MCP)-1 expression. Accordingly, angiotensin II itself increased MCP1 expression in atherosclerotic lesions, thus contributing to macrophage infiltration [68]. The crucial role of the reninangiotensin system in inflammatory processes regulating atherosclerosis was also observed in other animal models prone to develop atherosclerosis [69-74]. In these studies, various ACE inhibitors at doses comparable to those used clinically reduced atherosclerotic lesions independently of blood pressure. This was suggested by two independent findings: (1) the use of other antihypertensive drugs did not produce similar results [75]; (2) ACE inhibitors reduced atherosclerosis without altering blood pressure [69]. The beneficial effects of the renin-angiotensin pharmacological inhibition have been also observed in animal models of hypertension. The most used model was the "stroke-prone" strain (SHR-SP) rats. Treatment with ramipril in the prehypertensive phase in SHR-SP rats strongly reduced mortality and improved left-ventricular hypertrophy, cardiac and endothelial functions, and metabolism [76]. The administration of ACE inhibitors in the later phases of hypertension in SHR-SP rats also decreased mortality [77], suggesting that ACE inhibitors reduce cardiovascular risk and atherosclerosis in animals in different stages of cardiovascular disease. These benefits are confirmed by the majority of the published studies. However, some authors have also demonstrated 
that lowdose of trandolapril did not reduce both blood pressure and atherosclerosis in hyperlipidemic rabbits [78]. Similarly to ACEinhibitors, ARBs reduced blood pressure and atherosclerosis in different animal models [79-82]. However, differently from ACE inhibitors, the protective effect of ARBs was observed at both high and lowdoses. Although some authors did not confirm ARB-mediated benefits at low doses [83], a possible dose-dependent impact on atherogenesis, not only mediated by blood pressure lowering, is strongly suggested. No data are available on the use of ACE inhibitors and ARBs on atherogenesis in transgenic rats with inducible angiotensin II (Ang II)dependent hypertension (TGR[Cypla1-Ren2]), two kidneyone clip $(2 \mathrm{~K}-1 \mathrm{C})$ hypertension rats, or hypertensive double transgenic mice $(\mathrm{R}+/ \mathrm{A}+)$ that overexpress both human renin $(\mathrm{R}+)$ and human angiotensinogen $(\mathrm{A}+)$. Few evidences are available about the use of ACE inhibitors or ARBs on mouse models with local (intracardiac) or systemic high angiotensin II $[84,85]$. However, these studies were not focused on atherosclerosis. Therefore, further studies are needed to clarify the role of ACE inhibitors and ARBs in atherosclerosis in animal models with high angiotensin II levels. In March 2007, the US Food and Drud Administration approved a new renin-angiotensin blocker (aliskiren, a direct renin inhibitor) for the treatment of hypertension in humans without renal dysfunction. Renin inhibition blocks angiotensin I generation with the consequent suppression of angiotensin II as well as angiotensin peptide formation. Preclinical studies strongly supported the antihypertensive efficacy and safety of aliskiren [86]. Recent evidence also suggested a possible direct role of renin inhibitors to reduce atherosclerotic inflammation [87-89]. In a double-trangenic rat model (dTGR), overexpressing human renin and human angiotensinogen genes, aliskiren reduced cardiac hypertrophy, fibrosis, inflammation, and inducibility of arrhythmias [90] and reversed already established cardiac and renal damage [91]. The benicial effects of renin inhibition on organ damage are partially due to the suppression of hypertension. The blockade of direct proinflammatory activities of angiotensin II and angiotensin peptides represents a crucial mechanism to reduce atherosclerosis. In fact, in the same dTGR rat model, aliskiren and ARB losartan also reduced albuminuria and expression of inflammatory mediators, such as TNF- $\alpha, \mathrm{C}$-reactive protein (CRP) and complement $\mathrm{C} 1 \mathrm{q}, \mathrm{C} 3, \mathrm{C} 3 \mathrm{c}$, and C5b-9 in comparison with untreated controls [25]. Treatment with aliskiren has been also shown to protect against endothelial dysfunction and atherosclerosis in Watanabe heritable hyperlipidemic rabbits [89] as well as ApoE deficient [87] or LDL receptor deficient [92] mice.

\section{ACE Inhibitors, ARBs, and Renin Inhibitors in Atherosclerotic Inflammatory Processes: Clinical Trials}

At the beginning of the nineties, Dzau and Braunwald proposed the concept of the cardiovascular continuum in humans [103]: cardiovascular disease can be seen as a pathophysiologic cascade induced by the presence of risk factors, such as hypertension, hypercholesterolemia, diabetes mellitus, and smoking. These conditions can produce well defined stages, such as endothelial dysfunction, atherosclerosis, and target organ damage, followed ultimately by the clinical syndromes (heart failure, stroke, and end-stage renal disease) and eventually death. Experimental evidence clearly suggests a key role of the renin-angiotensin system and the induced inflammatory processes at all stages of this continuum and consequently a strong rationale for its blockade in order to prevent cardiovascular events [23]. The possibility of a positive effect of the renin-angiotensin blockade at the early stages of the cardiovascular continuum, that is, the endothelial dysfunction, was specifically addressed by some clinical studies. Although the complexity of the methodology applied to these investigations did not allow the recruitment of a very large number of patients, the results were clearly supportive about the role of the renin-angiotensin inhibition in the reversal of the endothelial dysfunction. Early evidence came from the TREND study [104], which showed that angiotensin-converting enzyme (ACE) inhibition with quinapril improves endothelial function of the coronary arteries. Similar results were obtained in the coronary circulation with the ARBs: valsartan improved basal nitric oxide production and release in hypertensive patients as compared to diuretic-treated subjects, despite similar blood pressure decrease [105]. The endothelial function was evaluated also in both the peripheral [106] and the renal circulation [107], always showing a consistent improvement exerted by the renin-angiotensin blockade. In addition, in a small group of hypertensive patients, resistance arteries obtained from subcutaneous biopsies were studied before and after 1 year of treatment with either an ARB (losartan) or a $\beta$-blocker (atenolol); basal measurements were compared to those of normotensive controls [108]. Despite similar reductions in blood pressure, losartan normalized acetylcholine-dependent vasodilation and reduced media/lumen ratio. Whereas different ARBs exert their effects on endothelial function in a similar way (through $\mathrm{AT}_{1}$ receptor antagonism) for $\mathrm{ACE}$ inhibitors we have to consider the presence of both plasma ACE, which regulates blood pressure, and tissue ACE, which is involved in the regulation of tissue inflammation, fibrosis, and hypertrophy [109]. In BANFF study, for example, an ACE inhibitor with low activity at the tissue level, enalapril, was not able to affect endothelial function [110]. More recently the TRENDY study tried to compare an ARB, telmisartan, and an ACE inhibitor, ramipril, in terms of improvement of the renal endothelial function [107]: no significant differences between the two drugs were observed although the ARB seemed to be a little more efficient. The demonstration of the prognostic significance of endothelial dysfunction was obtained from studies where it was possible to find an inverse association between the acetylcholine-stimulated forearm blood flow increase and the cumulative incidence of cardiovascular events [111]. Two other surrogate parameters, which have been evaluated in clinical studies extensively, are the circulating inflammatory markers and the extension of the vascular damage (carotid intima-media thickness [IMT], 
TABLE 1: Clinical studies evaluating effects of RAS blockade on circulating inflammatory markers. When two active drugs are administered, the effects demonstrated are with respect to basal values; when an active deug and placebo are used, the comparisons are between the two arms. CABG: coronary artery bypass grafting; ACEI: ACE inhibitors.

\begin{tabular}{|c|c|c|c|c|c|}
\hline Studies & Patients & Clinical conditions & Drugs & \multicolumn{2}{|c|}{ Main effects } \\
\hline \multirow[t]{2}{*}{ Sheth et al. [93] } & \multirow[t]{2}{*}{107} & \multirow[t]{2}{*}{ Chronic heart failure } & \multirow[t]{2}{*}{ Lisinopril versus Omapatrilat } & \multirow{2}{*}{\multicolumn{2}{|c|}{$\begin{array}{l}\uparrow \text { IL-10 (Omapatrilat) } \\
=\text { IL-6 }\end{array}$}} \\
\hline & & & & & \\
\hline \multirow{4}{*}{ Jilma et al. [94] } & \multirow{4}{*}{32} & \multirow{4}{*}{ Essential hypertension } & \multirow{4}{*}{ Enalapril versus Losartan } & $\downarrow$ E-selectin & \multirow{4}{*}{ Enalapril } \\
\hline & & & & $\downarrow$ ICAM-1 & \\
\hline & & & & $\downarrow$ VCAM-1 & \\
\hline & & & & $\downarrow \mathrm{MCP}-1$ & \\
\hline \multirow{3}{*}{ Koh et al. [95] } & \multirow{3}{*}{45} & \multirow{3}{*}{ Essential hypertension } & \multirow{3}{*}{ Candesartan versus Placebo } & $\downarrow \mathrm{MCP}-1$ & \\
\hline & & & & $\downarrow$ TNF- $\alpha$ & \\
\hline & & & & $=\mathrm{CRP}$ & \\
\hline Di Napoli and Papa [96] & 507 & Ischemic stroke & $\begin{array}{l}\text { ACEI versus Other } \\
\text { hypotensive drugs }\end{array}$ & $\downarrow \mathrm{CRP}$ & (ACEI) \\
\hline Tsikouris et al. [97] & 30 & Acute myocardial infarction & Quinapril versus Enalapril & $\downarrow \mathrm{CRP}($ & Quinapril) \\
\hline \multirow{4}{*}{ Schieffer et al. [98] } & \multirow{4}{*}{48} & \multirow{4}{*}{$\begin{array}{l}\text { Coronary artery disease Essential } \\
\text { hypertension }\end{array}$} & \multirow{4}{*}{ Enalapril versus Irbesartan } & $\uparrow$ IL-10 & \multirow{4}{*}{$\begin{array}{l}\text { Both } \\
\text { Irbesartan }\end{array}$} \\
\hline & & & & $\downarrow$ MMP-9 & \\
\hline & & & & $\downarrow$ IL-6 & \\
\hline & & & & $\downarrow \mathrm{CRP}$ & \\
\hline \multirow{4}{*}{ Fliser et al. [99] } & \multirow{4}{*}{199} & \multirow{4}{*}{$\begin{array}{l}\text { Essential hypertension and/or } \\
\text { Vascular disease Diabetes mellitus } \\
\text { LDL-C > } 150 \mathrm{mg} / \mathrm{dL}\end{array}$} & \multirow{4}{*}{ Olmesartan versus Placebo } & $\downarrow \mathrm{CRP}$ & \\
\hline & & & & $\downarrow$ TNF- $\alpha$ & \\
\hline & & & & $\downarrow$ IL-6 & \\
\hline & & & & $\downarrow \mathrm{MCP}-1$ & \\
\hline \multirow{4}{*}{ Trevelyan et al. [100] } & \multirow{4}{*}{45} & \multirow{4}{*}{ Angina pectoris awaiting $\mathrm{CABG}$} & \multirow{4}{*}{$\begin{array}{l}\text { Enalapril or Losartan versus } \\
\text { Control }\end{array}$} & $\downarrow$ IL-1ra & \\
\hline & & & & $\downarrow$ IL-6 & \\
\hline & & & & $=\mathrm{IL}-10$ & \\
\hline & & & & $=$ IL-8 n.d. & \\
\hline \multirow{4}{*}{ Tikiz et al. [101] } & \multirow{4}{*}{45} & \multirow{4}{*}{ Rheumatoid arthritis } & & $=\mathrm{CRP}$ & \\
\hline & & & Quinapril versus Placebo & $=\mathrm{TNF}-\alpha$ & \\
\hline & & & Qumapri versus PIacedo & $=\mathrm{IL}-1 \beta$ & \\
\hline & & & & $=$ IL-6 & \\
\hline Krysiak and Okopień [102] & 90 & Coronary artery disease & $\begin{array}{l}\text { Perindopril or Enalapril } \\
\text { versus Placebo }\end{array}$ & $\begin{array}{l}\downarrow \mathrm{MCP}-1 \\
\uparrow \mathrm{IL}-10\end{array}$ & Both \\
\hline & & & & $\downarrow \mathrm{CRP}$ & (Perindopril) \\
\hline
\end{tabular}

coronary circulation, and volume of the atherosclerotic plaques). Although ACE inhibitors reduce blood levels of inflammatory cytokines in vivo [102], this issue has been addressed more in depth for ARBs [112]. Table 1 lists a series of clinical studies, in which ACE inhibitors and ARBs reduce serum levels of inflammatory markers in different diseases [93-102]. As for vascular structure, the less invasive way to evaluate the possible atherosclerotic changes is the ultrasound determination of the carotid IMT. In the SECURE trial, a significant decrease in the progression slope of mean maximal IMT by $0.04 \mathrm{~mm}$ was observed in the active arm as compared to placebo [113]. These results were not confirmed by another study, the PART-2 trial, with the same active drug and the same parameter [114], and also by two studies (QUIET and SCAT) with a coronary angiographic evaluation $[115,116]$. More recently intravascular ultrasound (IVUS) was used in a substudy of the CAMELOT trial, which compared the effects of 3 different treatments on atherosclerosis progression: amlodipine, a calcium-antagonist, showed no progression; enalapril, an ACE inhibitor, a trend toward progression, which was more evident in the placebo group [117]. Also the effects of ARBs were evaluated at the vascular levels: in a substudy of the LIFE trial, losartan, an ARB, but not atenolol, a $\beta$-blocker, induced a regression of the carotid artery hypertrophy in hypertensive subjects [118]. The first successful clinical application of the experimental observations about the role of the renin-angiotensin in the cardiovascular pathophysiology was the demonstration of the ACE inhibitors as an undisputed treatment in patients with congestive heart failure or coronary artery disease (CAD) and concomitant left ventricular dysfunction, all clinical syndromes characterized by a strong activation of the renin-angiotensin system [119]. These results were subsequently confirmed by trials with ARBs [120]. The first 
studies (SAVE and SOLVD) demonstrated that these drugs reduced both mortality rate and risk of ischemic events [121]; moreover in SAVE the effect of the ACEinhibition by captopril was found to be independent of the degree of left ventricular dysfunction. These data suggested a primary antiischemic effect of the ACEinhibitors. Therefore a subsequent step was proposed to demonstrate a significant positive effect of the renin-angiotensin blockade in subjects at high risk for cardiovascular events but without left ventricular dysfunction. The HOPE study was the first randomized controlled trial that reached this goal: in high-risk patients ramipril was able to induce an important $22 \%$ risk reduction of composite cardiovascular death, MI, or stroke compared to placebo [122]. High-risk patients were defined as those with evidence of vascular disease $(\mathrm{CAD}$, stroke, peripheral vascular disease) or diabetes plus one other cardiovascular risk factor (hypertension, low high-density lipoprotein levels, elevated total cholesterol levels, smoking, microalbuminuria). The analysis of the results induced intense debate about the role of blood pressure decrease per se in the observed benefits [123]. The results in the HOPE study and in the subsequent similar trials with other ACEinhibitors occurred in a population of patients already receiving standard medical therapy, including platelet inhibitors, lipidlowering therapy, and $\beta$-blockers. Two large trials (EUROPA and PEACE) were performed to confirm HOPE study results with the same class of renin-angiotensin antagonists [124, 125]. The former was successful in demonstrating a similar (20\%) relative reduction of cardiovascular risk (primary end point of cardiovascular death, MI, or cardiac arrest); instead the latter was not able to show significant differences between treatment groups (ACEinhibitor versus placebo) in the primary end point, a composite of death resulting from cardiovascular causes, nonfatal MI, or revascularization. Several hypotheses have been put forward to explain these discrepancies [126]: the main reason could be the healthier conditions of the PEACE patients with respect to the patients enrolled in the other trials and therefore the difficulty for the active treatment to demonstrate clear positive effects on the outcomes. However a meta-analysis of the three placebo-controlled trials demonstrated a significant effect of ACE inhibition on the occurrence of all-cause mortality, cardiovascular mortality, nonfatal MI, stroke, heart failure, and coronary bypass surgery [127]. The same approach has been performed with an ARB in the TRANSCEND study [128]. The results have shown that the active treatment (telmisartan) was not superior to placebo in the prevention of cardiovascular events, primary composite end point represented by cardiovascular death, MI, stroke, or admission to the hospital for heart failure events. Ripley and Harrison suggest that these partially unexpected data could be explained by the differences in patient number, event rates, and the use of other life-saving drugs between TRANSCEND and HOPE studies [129]. However these results confirm the difficulty to demonstrate a significant effect of the renin-angiotensin blockade in the cardiovascular prevention beyond the blood pressure control. At present, the only suggestion of a therapeutical action which could be independent from the changes in blood pressure levels derives from the LIFE study [130]. In this large multicenter trial patients with left ventricular hypertrophy were randomized to receive treatment based on an ARB (losartan) or a $\beta$-blocker (atenolol): the composite primary end point of death, MI, and stroke was reduced by $13 \%$ with the ARB-based treatment compared with the $\beta$-blocker-based treatment in presence of a similar amount of blood pressure decrease. Another important issue is the mechanism of action of the different classes of renin-angiotensin blockers. If angiotensin II is the key player in the inflammatory processes in cardiovascular disease, we have many pharmacological ways to inhibit its synthesis; in addition the different classes of drugs demonstrate other effects, possibly related to a therapeutic gain (so called pleiotropic actions). In fact it is well known that ACE inhibitors are able to reduce the breakdown of bradykinin, and this molecule can cause the most frequent untoward effects of these drugs (cough, angioedema) but it is believed also as an important contributor to the protective cardiovascular effects exerted by them [131]. On the other hand, ARBs significantly increase angiotensin II levels, as a consequence of the antagonism at the $\mathrm{AT}_{1}$ receptor site. The possible role of the $\mathrm{AT}_{2}$ receptor stimulation in the beneficial therapeutic effects of ARB remains a fascinating hypothesis $[132,133]$. These pharmacological differences could explain the possible better results obtained with ACE inhibitors in terms of prevention of coronary events and with ARBs in terms of prevention of ischemic strokes [134] in comparison with the direct competitors for renin-angiotensin blockade. This therapeutic hypothesis has been verified by a systematic review of the available clinical data about the two classes of drugs [135] and by the recently published ONTARGET trial, a very large multicenter randomized trial in which the patients were treated with an ACE inhibitor (ramipril), an ARB (telmisartan), or the combination of the two drugs [136]. After a median follow-up of 56 months, the occurrence of the primary outcomes, consisting of death from cardiovascular causes, MI, stroke, or hospitalization for heart failure, was not significantly different in the ramipril and telmisartan groups, although the ARB was better tolerated. There were trends slightly favoring the ACE inhibitor for MI prevention and the ARB for stroke prevention but these differences did not reach statistical significance. The other issue addressed by the trial, the clinical role of the combined renin-angiotensin blockade, brought a word of caution about this strategy since more adverse events were observed $[137,138]$. Although in conditions of reninangiotensin hyperactivation, such as advanced heart failure, and of marked proteinuria the double blockade can still exert beneficial effects, other recent studies confirmed the possible risk of the combination in both a cardiological and a nephrological setting [139-141]. In 1957, Skeggs et al. suggested another possible approach to pharmacologically inhibit the renin-angiotensin system [142]. Renin inhibition was indicated as the preferred step to reduce angiotensin II effects. The discovery of prorenin receptor constitutes an additional reason to develop a new class of renin inhibitors [9]. An ambitious plan of primary and secondary prevention trials has begun in order to demonstrate possible advantages of the treatment with aliskiren alone or in combination with 
other renin-angiotensin blockers in patients with hypertension. At present, the effects independent of antihapertensive activity of aliskiren have been shown by one clinical trials focused on end-organ damage. In aliskiren in the evaluation of proteinuria in diabetes (AVOID) trial, the treatment with aliskiren reduced proteinuria independently of blood pressure [143]. Other clinical trials have been started to investigate the possible benefits of aliskiren in cardiac remodeling after myocardial infarction (AVANT GARDE, ASPIRE) and diabetic nephropathy (ALTITUTE) [144]. Therefore, in the next future, further clinical evidence will be available to confirm these preliminary anti-inflammatory and antiatherosclerotic effects of aliskiren in humans.

\section{Conclusions}

The inhibition of the renin-angiotensin system represents a pivotal approach for reducing atherosclerosis and its dramatic complications, such as stroke and myocardial infarction (MI). ACE inhibitors and ARBs are well-established pharmacological tools in both primary and secondary prevention of atherosclerotic cardiovascular disease. Emerging evidence shows that their beneficial effects are not only due to blood pressure lowering but also due to a direct antiinflammatory activity. Further studies are needed to better understand this promising investigation field, with particular interest for the promising results with the new renin inhibitor treatment.

\section{Acknowledgment}

The first and the second authors equally contributed as first author to this paper. This work was supported by Grants from the Swiss National Science Foundation to Dr. F. Mach (no. 320080-105836). The authors belong to the European Vascular Genomics Network (http://www.evgn.org/), a Network of Excellence supported by the European Community.

\section{References}

[1] G. K. Hansson, "Inflammation, atherosclerosis, and coronary artery disease," The New England Journal of Medicine, vol. 352, no. 16, pp. 1685-1695, 2005.

[2] P. Libby, "Inflammatory mechanisms: the molecular basis of inflammation and disease," Nutrition Reviews, vol. 65, supplement 3, pp. S140-S146, 2007.

[3] R. Toni, A. Malaguti, S. Castorina, E. Roti, and R. M. Lechan, "New paradigms in neuroendocrinology: relationships between obesity, systemic inflammation and the neuroendocrine system," Journal of Endocrinological Investigation, vol. 27, no. 2, pp. 182-186, 2004.

[4] D. S. Jacoby and D. J. Rader, "Renin-angiotensin system and atherothrombotic disease: from genes to treatment," Archives of Internal Medicine, vol. 163, no. 10, pp. 1155-1164, 2003.

[5] B. Schieffer and H. Drexler, "Role of 3-hydroxy-3methylglutaryl coenzyme a reductase inhibitors, angiotensinconverting enzyme inhibitors, cyclooxygenase-2 inhibitors, and aspirin in anti-inflammatory and immunomodulatory treatment of cardiovascular diseases," The American Journal of Cardiology, vol. 91, no. 12, supplement 1, pp. 12-18, 2003.
[6] R. Tigerstedt and P. G. Bergman, "Nere und Kreislauf," Skandinavisches Archiv für Physiologie, vol. 8, pp. 223-271, 1898.

[7] F. Fyhrquist and O. Saijonmaa, "Renin-angiotensin system revisited," Journal of Internal Medicine, vol. 264, no. 3, pp. 224-236, 2008.

[8] C. Guo, H. Ju, D. Leung, H. Massaeli, M. Shi, and M. Rabinovitch, "A novel vascular smooth muscle chymase is upregulated in hypertensive rats," The Journal of Clinical Investigation, vol. 107, no. 6, pp. 703-715, 2001.

[9] G. Nguyen, F. Delarue, C. Burcklé, L. Bouzhir, T. Giller, and J.-D. Sraer, "Pivotal role of the renin/prorenin receptor in angiotensin II production and cellular responses to renin," The Journal of Clinical Investigation, vol. 109, no. 11, pp. 1417-1427, 2002.

[10] M. Donoghue, F. Hsieh, E. Baronas, et al., "A novel angiotensin-converting enzyme-related carboxypeptidase (ACE2) converts angiotensin I to angiotensin 1-9," Circulation Research, vol. 87, no. 5, pp. E1-E9, 2000.

[11] S. R. Tipnis, N. M. Hooper, R. Hyde, E. Karran, G. Christie, and A. J. Turner, "A human homolog of angiotensinconverting enzyme: cloning and functional expression as a captopril-insensitive carboxypeptidase," The Journal of Biological Chemistry, vol. 275, no. 43, pp. 33238-33243, 2000.

[12] R. D. Stevanovic, D. A. Price, M. C. Lansang, N. D. L. Fisher, L. M. B. Laffel, and N. K. Hollenberg, "Renin release in response to renin system blockade: activation of the renin system in type 1 diabetes mellitus," Journal of the ReninAngiotensin-Aldosterone System, vol. 6, no. 2, pp. 78-83, 2005.

[13] C. M. Ferrario, "Angiotensin-converting enzyme 2 and angiotensin-(1-7): an evolving story in cardiovascular regulation," Hypertension, vol. 47, no. 3, pp. 515-521, 2006.

[14] L. M. Burrell, J. Risvanis, E. Kubota, et al., "Myocardial infarction increases ACE2 expression in rat and humans," European Heart Journal, vol. 26, no. 4, pp. 369-375, 2005.

[15] R. A. Santos and A. J. Ferreira, "Angiotensin-(1-7) and the renin-angiotensin system," Current Opinion in Nephrology and Hypertension, vol. 16, no. 2, pp. 122-128, 2007.

[16] Y. Hirono, T. Yoshimoto, N. Suzuki, et al., "Angiotensin II receptor type 1-mediated vascular oxidative stress and proinflammatory gene expression in aldosterone-induced hypertension: the possible role of local renin-angiotensin system," Endocrinology, vol. 148, no. 4, pp. 1688-1696, 2007.

[17] K. Tamura, Y. Tanaka, Y. Tsurumi, et al., "The role of angiotensin AT1 receptor-associated protein in reninangiotensin system regulation and function," Current Hypertension Reports, vol. 9, no. 2, pp. 121-127, 2007.

[18] L. Gendron, M. D. Payet, and N. Gallo-Payet, "The angiotensin type 2 receptor of angiotensin II and neuronal differentiation: from observations to mechanisms," Journal of Molecular Endocrinology, vol. 31, no. 3, pp. 359-372, 2003.

[19] L. A. Cassis, S. B. Police, F. Yiannikouris, and S. E. Thatcher, "Local adipose tissue renin-angiotensin system," Current Hypertension Reports, vol. 10, no. 2, pp. 93-98, 2008.

[20] V. P. Singh, B. Le, R. Khode, K. M. Baker, and R. Kumar, "Intracellular angiotensin II production in diabetic rats is correlated with cardiomyocyte apoptosis, oxidative stress, and cardiac fibrosis," Diabetes, vol. 57, no. 12, pp. 3297-3306, 2008.

[21] V. P. Singh, K. M. Baker, and R. Kumar, "Activation of the intracellular renin-angiotensin system in cardiac fibroblasts by high glucose: role in extracellular matrix production," American Journal of Physiology, vol. 294, no. 4, pp. H1675H1684, 2008. 
[22] R. Kumar, V. P. Singh, and K. M. Baker, "The intracellular renin-angiotensin system: implications in cardiovascular remodeling," Current Opinion in Nephrology and Hypertension, vol. 17, no. 2, pp. 168-173, 2008.

[23] R. E. Schmieder, K. F. Hilgers, M. P. Schlaich, and B. M. Schmidt, "Renin-angiotensin system and cardiovascular risk," The Lancet, vol. 369, no. 9568, pp. 1208-1219, 2007.

[24] M. Graninger, R. Reiter, C. Drucker, E. Minar, and B. Jilma, "Angiotensin receptor blockade decreases markers of vascular inflammation," Journal of Cardiovascular Pharmacology, vol. 44, no. 3, pp. 335-339, 2004.

[25] E. Shagdarsuren, M. Wellner, J.-H. Braesen, et al., "Complement activation in angiotensin II-induced organ damage," Circulation Research, vol. 97, no. 7, pp. 716-724, 2005.

[26] M. Epstein, "Aldosterone and the hypertensive kidney: its emerging role as a mediator of progressive renal dysfunction: a paradigm shift," Journal of Hypertension, vol. 19, no. 5, pp. 829-842, 2001.

[27] K. Sean Eardley and P. Cockwell, "Macrophages and progressive tubulointerstitial disease," Kidney International, vol. 68, no. 2, pp. 437-455, 2005.

[28] M. Fukuhara, R. L. Geary, D. I. Diz, et al., "Angiotensinconverting enzyme expression in human carotid artery atherosclerosis," Hypertension, vol. 35, no. 1, part 2, pp. 353359, 2000.

[29] M. Ohishi, M. Ueda, H. Rakugi, et al., "Enhanced expression of angiotensin-converting enzyme is associated with progression of coronary atherosclerosis in humans," Journal of Hypertension, vol. 15, no. 11, pp. 1295-1302, 1997.

[30] U. N. Das, "Is angiotensin-II an endogenous proinflammatory molecule?" Medical Science Monitor, vol. 11, no. 5, pp. RA155-RA162, 2005.

[31] C. M. Ferrario and W. B. Strawn, "Role of the reninangiotensin-aldosterone system and proinflammatory mediators in cardiovascular disease," The American Journal of Cardiology, vol. 98, no. 1, pp. 121-128, 2006.

[32] C.-H. Wang, S.-H. Li, R. D. Weisel, et al., "C-reactive protein upregulates angiotensin type 1 receptors in vascular smooth muscle," Circulation, vol. 107, no. 13, pp. 1783-1790, 2003.

[33] K. M. Schmidt-Ott, S. Kagiyama, and M. I. Phillips, "The multiple actions of angiotensin II in atherosclerosis," Regulatory Peptides, vol. 93, no. 1-3, pp. 65-77, 2000.

[34] S. Keidar, M. Kaplan, A. Hoffman, and M. Aviram, "Angiotensin II stimulates macrophage-mediated oxidation of low density lipoproteins," Atherosclerosis, vol. 115, no. 2, pp. 201-215, 1995.

[35] H. Morawietz, U. Rueckschloss, B. Niemann, et al., "Angiotensin II induces LOX-1, the human endothelial receptor for oxidized low-density lipoprotein," Circulation, vol. 100, no. 9, pp. 899-902, 1999.

[36] B. A. Schölkens and W. Landgraf, "ACE inhibition and atherogenesis," Canadian Journal of Physiology and Pharmacology, vol. 80, no. 4, pp. 354-359, 2002.

[37] W. Linz, P. Wohlfart, B. A. Schölkens, R. H. A. Becker, T. Malinski, and G. Wiemer, "Late treatment with ramipril increases survival in old spontaneously hypertensive rats," Hypertension, vol. 34, no. 2, pp. 291-295, 1999.

[38] G. Wiemer, B. A. Schölkens, R. H. A. Becker, and R. Busse, "Ramiprilat enhances endothelial autacoid formation by inhibiting breakdown of endothelium-derived bradykinin," Hypertension, vol. 18, no. 4, pp. 558-563, 1991.

[39] G. Wiemer, B. A. Schölkens, and W. Linz, "Endothelial protection by converting enzyme inhibitors," Cardiovascular Research, vol. 28, no. 2, pp. 166-172, 1994.
[40] T. Malinski, S. Mesáros, S. R. Patton, and A. Mesárosová, "Direct measurement of nitric oxide in the cardiovascular system," Physiological Research, vol. 45, no. 4, pp. 279-284, 1996.

[41] R. Kranzhöfer, M. Browatzki, J. Schmidt, and W. Kübler, "Angiotensin II activates the proinflammatory transcription factor nuclear factor- $\kappa \mathrm{B}$ in human monocytes," Biochemical and Biophysical Research Communications, vol. 257, no. 3, pp. 826-828, 1999.

[42] R. Kranzhöfer, J. Schmidt, C. A. H. Pfeiffer, S. Hagl, P. Libby, and W. Kübler, "Angiotensin induces inflammatory activation of human vascular smooth muscle cells," Arteriosclerosis, Thrombosis, and Vascular Biology, vol. 19, no. 7, pp. 16231629, 1999.

[43] K. Brand, S. Page, G. Rogler, et al., "Activated transcription factor nuclear factor-kappa B is present in the atherosclerotic lesion," The Journal of Clinical Investigation, vol. 97, no. 7, pp. 1715-1722, 1996.

[44] T. J. Guzik and D. G. Harrison, "Endothelial NF- $\kappa$ B as a mediator of kidney damage: the missing link between systemic vascular and renal disease?" Circulation Research, vol. 101, no. 3, pp. 227-229, 2007.

[45] N. Henke, R. Schmidt-Ullrich, R. Dechend, et al., "Vascular endothelial cell-specific NF- $\kappa$ B suppression attenuates hypertension-induced renal damage," Circulation Research, vol. 101, no. 3, pp. 268-276, 2007.

[46] M. Takahashi, E. Suzuki, R. Takeda, et al., "Angiotensin II and tumor necrosis factor- $\alpha$ synergistically promote monocyte chemoattractant protein-1 expression: roles of NF- $\kappa \mathrm{B}, \mathrm{p} 38$, and reactive oxygen species," American Journal of Physiology, vol. 294, no. 6, pp. H2879-H2888, 2008.

[47] E. Blessing, M. Preusch, R. Kranzhöfer, et al., "Antiatherosclerotic properties of telmisartan in advanced atherosclerotic lesions in apolipoprotein E deficient mice," Atherosclerosis, vol. 199, no. 2, pp. 295-303, 2008.

[48] G. Chinetti, S. Griglio, M. Antonucci, et al., "Activation of proliferator-activated receptors $\alpha$ and $\gamma$ induces apoptosis of human monocyte-derived macrophages," The Journal of Biological Chemistry, vol. 273, no. 40, pp. 25573-25580, 1998.

[49] H. Kato, J. Ishida, K. Nagano, et al., "Deterioration of atherosclerosis in mice lacking angiotensin II type 1A receptor in bone marrow-derived cells," Laboratory Investigation, vol. 88, no. 7, pp. 731-739, 2008.

[50] R. E. Pratt, "Angiotensin II and the control of cardiovascular structure," Journal of the American Society of Nephrology, vol. 10, supplement 11, pp. S120-S128, 1999.

[51] J. Sadoshima, "Cytokine actions of angiotensin II," Circulation Research, vol. 86, no. 12, pp. 1187-1189, 2000.

[52] M. Ruiz-Ortega, O. Lorenzo, M. Rupérez, V. Esteban, S. Mezzano, and J. Egido, "Renin-angiotensin system and renal damage: emerging data on angiotensin II as a proinflammatory mediator," Contributions to Nephrology, vol. 135, pp. 123-137, 2001.

[53] V. J. Dzau, "Mechanism of protective effects of ACE inhibition on coronary artery disease," European Heart Journal, vol. 19, supplement J, pp. J2-J6, 1998.

[54] G. B. J. Mancini, "Role of angiotensin-converting enzyme inhibition in reversal of endothelial dysfunction in coronary artery disease," The American Journal of Medicine, vol. 105, no. 1, supplement 1, pp. 40S-47S, 1998.

[55] K. F. Adams Jr., "Angiotensin-converting enzyme inhibition and vascular remodeling in coronary artery disease," Coronary Artery Disease, vol. 9, no. 10, pp. 675-684, 1998. 
[56] Y. A. Ding, D. E. MacIntyre, C. J. Kenyon, and P. F. Semple, "Potentiation of adrenaline-induced platelet aggregation by angiotensin II," Thrombosis and Haemostasis, vol. 54, no. 3, pp. 717-720, 1985.

[57] H. Soejima, H. Ogawa, H. Yasue, et al., "Angiotensinconverting enzyme inhibition reduces monocyte chemoattractant protein-1 and tissue factor levels in patients with myocardial infarction," Journal of the American College of Cardiology, vol. 34, no. 4, pp. 983-988, 1999.

[58] A. Ichihara, M. Hayashi, N. Hirota, et al., "Angiotensin II type 2 receptor inhibits prorenin processing in juxtaglomerular cells," Hypertension Research, vol. 26, no. 11, pp. 915-921, 2003.

[59] S. Apostolakis, E. Krambovitis, Z. Vlata, G. E. Kochiadakis, S. Baritaki, and D. A. Spandidos, "CX3CR1 receptor is upregulated in monocytes of coronary artery diseased patients: impact of pre-inflammatory stimuli and renin-angiotensin system modulators," Thrombosis Research, vol. 121, no. 3, pp. 387-395, 2007.

[60] T. Inukai, N. Yoshida, S. Wakabayashi, et al., "Angiotensinconverting enzyme inhibitors and angiotensin II receptor blockers effectively and directly potentiate superoxide scavenging by polymorphonuclear leukocytes from patients with type 2 diabetes mellitus," American Journal of the Medical Sciences, vol. 329, no. 5, pp. 222-227, 2005.

[61] M. Schupp, J. Janke, R. Clasen, T. Unger, and U. Kintscher, "Angiotensin type 1 receptor blockers induce peroxisome proliferator-activated receptor- $\gamma$ activity," Circulation, vol. 109, no. 17, pp. 2054-2057, 2004.

[62] J. Janke, M. Schupp, S. Engeli, et al., "Angiotensin type 1 receptor antagonists induce human in-vitro adipogenesis through peroxisome proliferator-activated receptor- $\gamma$ activation," Journal of Hypertension, vol. 24, no. 9, pp. 1809-1816, 2006.

[63] N. Jia, H. Okamoto, T. Shimizu, et al., "A newly developed angiotensin II type 1 receptor antagonist, CS866, promotes regression of cardiac hypertrophy by reducing integrin $\beta_{1}$ expression," Hypertension Research, vol. 26, no. 9, pp. $737-$ 742, 2003.

[64] B. A. Schölkens, R. H. A. Becker, and J. Kaiser, "Cardiovascular and antihypertensive activities of the novel non-sulfhydryl converting enzyme inhibitor 2-[N-[(S)1-ethoxycarbonyl-3-phenylpropyl]-L-alanyl]-(1S,3S,5S)-2azabicyclo[3.3.0] octane-3-carboxylic acid (Hoe 498)," Arzneimittel-Forschung, vol. 34, no. 10B, pp. 1417-1425, 1984.

[65] P. A. Martorana, H. Ruetten, B. Goebel, et al., "Ramiprilat prevents the development of acute coronary endothelial dysfunction in the dog," Basic Research in Cardiology, vol. 94, no. 4, pp. 238-245, 1999.

[66] R. H. A. Becker, G. Wiemer, and W. Linz, "Preservation of endothelial function by ramipril in rabbits on a long-term atherogenic diet," Journal of Cardiovascular Pharmacology, vol. 18, supplement 2, pp. S110-S115, 1991.

[67] A. V. Chobanian, C. C. Haudenschild, C. Nickerson, and S. Hope, "Trandolapril inhibits atherosclerosis in the Watanabe heritable hyperlipidemic rabbit," Hypertension, vol. 20, no. 4, pp. 473-477, 1992.

[68] M. Hernández-Presa, C. Bustos, M. Ortego, et al., "Angiotensin-converting enzyme inhibition prevents arterial nuclear factor- $\kappa \mathrm{B}$ activation, monocyte chemoattractant protein-1 expression, and macrophage infiltration in a rabbit model of early accelerated atherosclerosis," Circulation, vol. 95, no. 6, pp. 1532-1541, 1997.
[69] S. Keidar, J. Attias, R. Coleman, K. Wirth, B. Schölkens, and T. Hayek, "Attenuation of atherosclerosis in apolipoprotein E-deficient mice by ramipril is dissociated from its antihypertensive effect and from potentiation of bradykinin," Journal of Cardiovascular Pharmacology, vol. 35, no. 1, pp. 64-72, 2000.

[70] M. Akishita, M. Horiuchi, H. Yamada, et al., "Inflammation influences vascular remodeling through AT2 receptor expression and signaling," Physiological Genomics, vol. 2, no. 1, pp. 13-20, 2000.

[71] M. Akishita, G. Shirakami, M. Iwai, et al., "Angiotensin converting enzyme inhibitor restrains inflammation-induced vascular injury in mice," Journal of Hypertension, vol. 19, no. 6, pp. 1083-1088, 2001.

[72] R. Candido, K. A. Jandeleit-Dahm, Z. Cao, et al., "Prevention of accelerated atherosclerosis by angiotensin-converting enzyme inhibition in diabetic apolipoprotein E-deficient mice," Circulation, vol. 106, no. 2, pp. 246-253, 2002.

[73] T. Hayek, M. Kaplan, A. Raz, S. Keidar, R. Coleman, and M. Aviram, "Ramipril administration to atherosclerotic mice reduces oxidized low-density lipoprotein uptake by their macrophages and blocks the progression of atherosclerosis," Atherosclerosis, vol. 161, no. 1, pp. 65-74, 2002.

[74] M. Miyazaki, H. Sakonjo, and S. Takai, "Anti-atherosclerotic effects of an angiotensin converting enzyme inhibitor and an angiotensin II antagonist in Cynomolgus monkeys fed a highcholesterol diet," British Journal of Pharmacology, vol. 128, no. 3, pp. 523-529, 1999.

[75] A. V. Chobanian, "The effects of ACE inhibitors and other antihypertensive drugs on cardiovascular risk factors and atherogenesis," Clinical Cardiology, vol. 13, no. 6, supplement 7, pp. 43-48, 1990.

[76] W. Linz, T. Jessen, R. H. A. Becker, B. A. Schölkens, and G. Wiemer, "Long-term ACE inhibition doubles lifespan of hypertensive rats," Circulation, vol. 96, no. 9, pp. 3164-3172, 1997.

[77] W. Linz, P. Wohlfart, B. A. Schölkens, T. Malinski, and G. Wiemer, "Interactions among ACE, kinins and NO," Cardiovascular Research, vol. 43, no. 3, pp. 549-561, 1999.

[78] A. V. Chobanian, C. C. Haudenschild, C. Nickerson, and S. Hope, "Trandolapril inhibits atherosclerosis in the Watanabe heritable hyperlipidemic rabbit," Hypertension, vol. 20, no. 4, pp. 473-477, 1992.

[79] S. Kim and H. Iwao, "Molecular and cellular mechanisms of angiotensin II-mediated cardiovascular and renal diseases," Pharmacological Reviews, vol. 52, no. 1, pp. 11-34, 2000.

[80] S. Hope, P. Brecher, and A. V. Chobanian, "Comparison of the effects of $\mathrm{AT}_{1}$ receptor blockade and angiotensin converting enzyme inhibition on atherosclerosis," American Journal of Hypertension, vol. 12, no. 1, pp. 28-34, 1999.

[81] J. Li, N. Hirose, M. Kawamura, and Y. Arai, "Antiatherogenic effect of angiotensin converting enzyme inhibitor (benazepril) and angiotensin II receptor antagonist (valsar$\tan$ ) in the cholesterol-fed rabbits," Atherosclerosis, vol. 143, no. 2, pp. 315-326, 1999.

[82] W. B. Strawn, M. C. Chappell, R. H. Dean, S. Kivlighn, and C. M. Ferrario, "Inhibition of early atherogenesis by losartan in monkeys with diet-induced hypercholesterolemia," Circulation, vol. 101, no. 13, pp. 1586-1593, 2000.

[83] H. Koike, "New pharmacologic aspects of CS-866, the newest angiotensin II receptor antagonist," The American Journal of Cardiology, vol. 87, no. 8, supplement 1, pp. 33-36, 2001. 
[84] A. J. Schuhmacher, C. Guerra, V. Sauzeau, M. Cañamero, X. R. Bustelo, and M. Barbacid, "A mouse model for Costello syndrome reveals an Ang II-mediated hypertensive condition," The Journal of Clinical Investigation, vol. 118, no. 6, pp. 2169-2179, 2008.

[85] J. P. van Kats, D. Methot, P. Paradis, D. W. Silversides, and T. L. Reudelhuber, "Use of a biological peptide pump to study chronic peptide hormone action in transgenic mice: direct and indirect effects of angiotensin II on the heart," The Journal of Biological Chemistry, vol. 276, no. 47, pp. 4401244017, 2001.

[86] K. K. Daugherty, “Aliskiren," American Journal of HealthSystem Pharmacy, vol. 65, no. 14, pp. 1323-1332, 2008.

[87] J. Nussberger, J.-F. Aubert, K. Bouzourene, M. Pellegrin, D. Hayoz, and L. Mazzolai, "Renin inhibition by aliskiren prevents atherosclerosis progression: comparison with irbesartan, atenolol, and amlodipine," Hypertension, vol. 51, no. 5, pp. 1306-1311, 2008.

[88] D. N. Müller, W. Derer, and R. Dechend, "Aliskiren-mode of action and preclinical data," Journal of Molecular Medicine, vol. 86, no. 6, pp. 659-662, 2008.

[89] T. Imanishi, H. Tsujioka, H. Ikejima, et al., "Renin inhibitor aliskiren improves impaired nitric oxide bioavailability and protects against atherosclerotic changes," Hypertension, vol. 52, no. 3, pp. 563-572, 2008.

[90] R. Fischer, R. Dechend, F. Qadri, et al., "Dietary n3 polyunsaturated fatty acids and direct renin inhibition improve electrical remodeling in a model of high human renin hypertension," Hypertension, vol. 51, no. 2, pp. 540546, 2008.

[91] B. Pilz, E. Shagdarsuren, M. Wellner, et al., "Aliskiren, a human renin inhibitor, ameliorates cardiac and renal damage in double-transgenic rats," Hypertension, vol. 46, no. 3, pp. 569-576, 2005.

[92] H. Lu, D. L. Rateri, D. L. Feldman, et al., "Renin inhibition reduces hypercholesterolemia-induced atherosclerosis in mice," The Journal of Clinical Investigation, vol. 118, no. 3, pp. 984-993, 2008.

[93] T. Sheth, T. Parker, A. Block, et al., "Comparison of the effects of omapatrilat and lisinopril on circulating neurohormones and cytokines in patients with chronic heart failure," The American Journal of Cardiology, vol. 90, no. 5, pp. 496-500, 2002.

[94] B. Jilma, F. L. Li-Saw-Hee, O. F. Wagner, D. G. Beevers, and G. Y. H. Lip, "Effects of enalapril and losartan on circulating adhesion molecules and monocyte chemotactic protein-1," Clinical Science, vol. 103, no. 2, pp. 131-136, 2002.

[95] K. K. Koh, J. Y. Ahn, S. H. Han, et al., "Pleiotropic effects of angiotensin II receptor blocker in hypertensive patients," Journal of the American College of Cardiology, vol. 42, no. 5, pp. 905-910, 2003.

[96] M. Di Napoli and F. Papa, "Angiotensin-converting enzyme inhibitor use is associated with reduced plasma concentration of C-reactive protein in patients with first-ever ischemic stroke," Stroke, vol. 34, no. 12, pp. 2922-2929, 2003.

[97] J. P. Tsikouris, J. A. Suarez, J. S. Simoni, M. Ziska, and G. E. Meyerrose, "Exploring the effects of ACE inhibitor tissue penetration on vascular inflammation following acute myocardial infarction," Coronary Artery Disease, vol. 15, no. 4, pp. 211-217, 2004.

[98] B. Schieffer, C. Bünte, J. Witte, et al., "Comparative effects of AT1-antagonism and angiotensin-converting enzyme inhibition on markers of inflammation and platelet aggregation in patients with coronary artery disease," Journal of the American College of Cardiology, vol. 44, no. 2, pp. 362-368, 2004.

[99] D. Fliser, K. Buchholz, and H. Haller, "Antiinflammatory effects of angiotensin II subtype 1 receptor blockade in hypertensive patients with microinflammation," Circulation, vol. 110, no. 9, pp. 1103-1107, 2004.

[100] J. Trevelyan, D. J. Brull, E. W. A. Needham, H. E. Montgomery, A. Morris, and R. K. Mattu, "Effect of enalapril and losartan on cytokines in patients with stable angina pectoris awaiting coronary artery bypass grafting and their interaction with polymorphisms in the interleukin-6 gene," The American Journal of Cardiology, vol. 94, no. 5, pp. 564569, 2004.

[101] C. Tikiz, O. Utuk, T. Pirildar, et al., "Effects of angiotensinconverting enzyme inhibition and statin treatment on inflammatory markers and endothelial functions in patients with longterm rheumatoid arthritis," Journal of Rheumatology, vol. 32, no. 11, pp. 2095-2101, 2005.

[102] R. Krysiak and B. Okopień, "Pleiotropic effects of angiotensin-converting enzyme inhibitors in normotensive patients with coronary artery disease," Pharmacological Reports, vol. 60, no. 4, pp. 514-523, 2008.

[103] V. Dzau and E. Braunwald, "Resolved and unresolved issues in the prevention and treatment of coronary artery disease: a workshop consensus statement," American Heart Journal, vol. 121, no. 4, part 1, pp. 1244-1263, 1991.

[104] G. B. J. Mancini, G. C. Henry, C. Macaya, et al., "Angiotensinconverting enzyme inhibition with quinapril improves endothelial vasomotor dysfunction in patients with coronary artery disease: the TREND (Trial on Reversing ENdothelial Dysfunction) study," Circulation, vol. 94, no. 3, pp. 258-265, 1996.

[105] A. U. Klingbeil, S. John, M. P. Schneider, J. Jacobi, G. Weidinger, and R. E. Schmieder, "AT 1 -receptor blockade improves augmentation index: a double-blind, randomized, controlled study," Journal of Hypertension, vol. 20, no. 12, pp. 2423-2428, 2002.

[106] B. Hornig, U. Landmesser, C. Kohler, et al., "Comparative effect of ACE inhibition and angiotensin II type 1 receptor antagonism on bioavailability of nitric oxide in patients with coronary artery disease: role of superoxide dismutase," Circulation, vol. 103, no. 6, pp. 799-805, 2001.

[107] R. E. Schmieder, C. Delles, A. Mimran, J. P. Fauvel, and L. M. Ruilope, "Impact of telmisartan versus ramipril on renal endothelial function in patients with hypertension and type 2 diabetes," Diabetes Care, vol. 30, no. 6, pp. 1351-1356, 2007.

[108] E. L. Schiffrin, J. B. Park, H. D. Intengan, and R. M. Touyz, "Correction of arterial structure and endothelial dysfunction in human essential hypertension by the angiotensin receptor antagonist losartan," Circulation, vol. 101, no. 14, pp. 1653$1659,2000$.

[109] M. Bader and D. Ganten, "Update on tissue reninangiotensin systems," Journal of Molecular Medicine, vol. 86, no. 6, pp. 615-621, 2008.

[110] T. J. Anderson, E. Elstein, H. Haber, and F. Charbonneau, "Comparative study of ACE-inhibition, angiotensin II antagonism, and calcium channel blockade on flow-mediated vasodilation in patients with coronary disease (BANFF study)," Journal of the American College of Cardiology, vol. 35, no. 1, pp. 60-66, 2000.

[111] F. Perticone, R. Ceravolo, A. Pujia, et al., "Prognostic significance of endothelial dysfunction in hypertensive patients," Circulation, vol. 104, no. 2, pp. 191-196, 2001. 
[112] C. Sierra and A. de la Sierra, "Antihypertensive, cardiovascular, and pleiotropic effects of angiotensin-receptor blockers," Current Opinion in Nephrology and Hypertension, vol. 14, no. 5, pp. 435-441, 2005.

[113] E. M. Lonn, S. Yusuf, V. Dzavik, et al., "Effects of Ramipril and vitamin $\mathrm{E}$ on atherosclerosis: the study to evaluate carotid ultrasound changes in patients treated with ramipril and vitamin E (SECURE)," Circulation, vol. 103, no. 7, pp. 919-925, 2001.

[114] S. MacMahon, N. Sharpe, G. Gamble, et al., "Randomized, placebo-controlled trial of the angiotensin-converting enzyme inhibitor, ramipril, in patients with coronary or other occlusive arterial disease," Journal of the American College of Cardiology, vol. 36, no. 2, pp. 438-443, 2000.

[115] K. K. Teo, J. R. Burton, C. E. Buller, et al., "Long-term effects of cholesterol lowering and angiotensin-converting enzyme inhibition on coronary atherosclerosis: the Simvastatin/Enalapril Coronary Atherosclerosis Trial (SCAT)," Circulation, vol. 102, no. 15, pp. 1748-1754, 2000.

[116] L. Cashin-Hemphill, G. Holmvang, R. C. Chan, B. Pitt, R. E. Dinsmore, and R. S. Lees, "Angiotensin-converting enzyme inhibition as antiatherosclerotic therapy: no answer yet," The American Journal of Cardiology, vol. 83, no. 1, pp. 43-47, 1999.

[117] S. E. Nissen, E. M. Tuzcu, P. Libby, et al., "Effect of antihypertensive agents on cardiovascular events in patients with coronary disease and normal blood pressure: the CAMELOT study: a randomized controlled trial," The Journal of the American Medical Association, vol. 292, no. 18, pp. 22172225, 2004.

[118] M. H. Olsen, K. Wachtell, K. Neland, et al., "Losartan but not atenolol reduce carotid artery hypertrophy in essential hypertension. A LIFE substudy," Blood Pressure, vol. 14, no. 3, pp. 177-183, 2005.

[119] M. R. Weir, "Effects of renin-angiotensin system inhibition end-organ protection: can we do better?" Clinical Therapeutics, vol. 29, no. 9, pp. 1803-1824, 2007.

[120] C. M. Ferrario, "Role of angiotensin II in cardiovascular disease therapeutic implications of more than a century of research," Journal of the Renin-Angiotensin-Aldosterone System, vol. 7, no. 1, pp. 3-14, 2006.

[121] L. M. Prisant, "Management of hypertension in patients with cardiac disease: use of renin-angiotensin blocking agents," The American Journal of Medicine, vol. 121, no. 8, supplement 1, pp. S8-S15, 2008.

[122] S. Yusuf, P. Sleight, J. Pogue, J. Bosch, R. Davies, and G. Dagenais, "Effects of an angiotensin-converting-enzyme inhibitor, ramipril, on cardiovascular events in high-risk patients," The New England Journal of Medicine, vol. 342, no. 3, pp. 145-153, 2000.

[123] P. S. Sever, N. R. Poulter, W. J. Elliott, et al., "Blood pressure reduction is not the only determinant of outcome," Circulation, vol. 113, no. 23, pp. 2754-2774, 2006.

[124] K. M. Fox, "Efficacy of perindopril in reduction of cardiovascular events among patients with stable coronary artery disease: randomised, double-blind, placebo-controlled, multicentre trial (the EUROPA study)," The Lancet, vol. 362, no. 9386, pp. 782-788, 2003.

[125] E. Braunwald, M. J. Domanski, S. E. Fowler, et al., "Angiotensin-converting-enzyme inhibition in stable coronary artery disease," The New England Journal of Medicine, vol. 351, no. 20, pp. 2058-2068, 2004.
[126] E. B. Friedrich, K. K. Teo, and M. Böhm, "ACE inhibition in secondary prevention: are the results controversial?" Clinical Research in Cardiology, vol. 95, no. 2, pp. 61-67, 2006.

[127] G. R. Dagenais, J. Pogue, K. Fox, M. L. Simoons, and S. Yusuf, "Angiotensin-converting-enzyme inhibitors in stable vascular disease without left ventricular systolic dysfunction or heart failure: a combined analysis of three trials," The Lancet, vol. 368, no. 9535, pp. 581-588, 2006.

[128] S. Yusuf, K. Teo, C. Anderson, et al., "Effects of the angiotensin-receptor blocker telmisartan on cardiovascular events in high-risk patients intolerant to angiotensinconverting enzyme inhibitors: a randomised controlled trial," The Lancet, vol. 372, no. 9644, pp. 1174-1183, 2008.

[129] T. L. Ripley and D. Harrison, "The power to TRANSCEND," The Lancet, vol. 372, no. 9644, pp. 1128-1130, 2008.

[130] B. Dahlöf, R. B. Devereux, S. E. Kjeldsen, et al., "Cardiovascular morbidity and mortality in the Losartan Intervention For Endpoint reduction in hypertension study (LIFE): a randomised trial against atenolol," The Lancet, vol. 359, no. 9311, pp. 995-1003, 2002.

[131] T. Watanabe, T. A. Barker, and B. C. Berk, "Angiotensin II and the endothelium: diverse signals and effects," Hypertension, vol. 45, no. 2, pp. 163-169, 2005.

[132] M. Moser, C. Rosendorff, and W. B. White, "Angiotensinconverting enzyme inhibitors and angiotensin II receptor blockers: is there a difference in response and any advantage to using them together in the treatment of hypertension?" Journal of Clinical Hypertension, vol. 10, no. 6, pp. 489-496, 2008.

[133] I. H. Schulman and L. Raij, "The angiotensin II type 2 receptor: what is its clinical significance?" Current Hypertension Reports, vol. 10, no. 3, pp. 188-193, 2008.

[134] F. H. Messerli, B. Williams, and E. Ritz, "Essential hypertension," The Lancet, vol. 370, no. 9587, pp. 591-603, 2007.

[135] D. B. Matchar, D. C. McCrory, L. A. Orlando, et al., "Systematic review: comparative effectiveness of angiotensinconverting enzyme inhibitors and angiotensin II receptor blockers for treating essential hypertension," Annals of Internal Medicine, vol. 148, no. 1, pp. 16-29, 2008.

[136] S. Yusuf, K. K. Teo, J. Pogue, et al., "Telmisartan, ramipril, or both in patients at high risk for vascular events," The New England Journal of Medicine, vol. 358, no. 15, pp. 1547-1559, 2008.

[137] J. F. Mann, R. E. Schmieder, M. McQueen, et al., "Renal outcomes with telmisartan, ramipril, or both, in people at high vascular risk (the ONTARGET study): a multicentre, randomised, double-blind, controlled trial," The Lancet, vol. 372, no. 9638, pp. 547-553, 2008.

[138] C. O. Phillips, A. Kashani, D. K. Ko, G. Francis, and H. M. Krumholz, "Adverse effects of combination angiotensin II receptor blockers plus angiotensin-converting enzyme inhibitors for left ventricular dysfunction: a quantitative review of data from randomized clinical trials," Archives of Internal Medicine, vol. 167, no. 18, pp. 1930-1936, 2007.

[139] R. Kunz, C. Friedrich, M. Wolbers, and J. F. E. Mann, "Meta-analysis: effect of monotherapy and combination therapy with inhibitors of the renin-angiotensin system on proteinuria in renal disease," Annals of Internal Medicine, vol. 148, no. 1, pp. 30-48, 2008.

[140] J. J. V. McMurray, J. Östergren, K. Swedberg, et al., "Effects of candesartan in patients with chronic heart failure and reduced left-ventricular systolic function taking angiotensinconverting-enzyme inhibitors: the CHARM-added trial," The Lancet, vol. 362, no. 9386, pp. 767-771, 2003. 
[141] P. Ferrari, H.-P. Marti, M. Pfister, and F. J. Frey, "Additive antiproteinuric effect of combined ACE inhibition and angiotensin II receptor blockade," Journal of Hypertension, vol. 20, no. 1, pp. 125-130, 2002.

[142] L. T. Skeggs Jr., J. R. Kahn, K. Lentz, and N. P. Shumway, "The preparation, purification, and amino acid sequence of a polypeptide renin substrate," The Journal of Experimental Medicine, vol. 106, no. 3, pp. 439-453, 1957.

[143] H.-H. Parving, F. Persson, J. B. Lewis, E. J. Lewis, and N. K. Hollenberg, "Aliskiren combined with losartan in type 2 diabetes and nephropathy," The New England Journal of Medicine, vol. 358, no. 23, pp. 2433-2446, 2008.

[144] D. Westermann, R. Schmieder, H.-P. Schultheiss, and C. Tschöpe, "Renin inhibitors, clinical experience," Journal of Molecular Medicine, vol. 86, no. 6, pp. 691-695, 2008. 


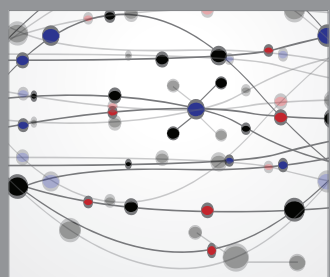

The Scientific World Journal
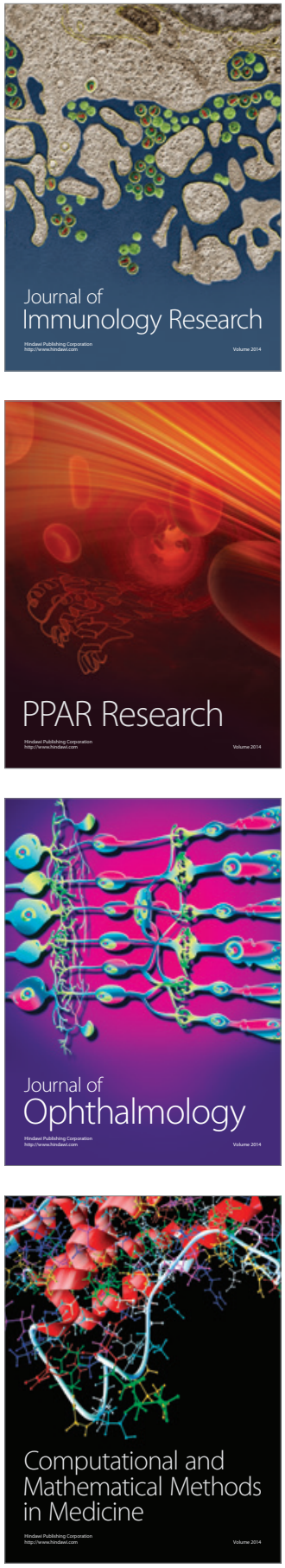

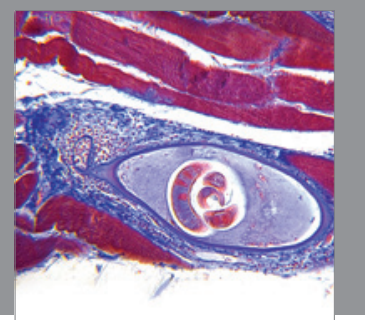

Gastroenterology

Research and Practice
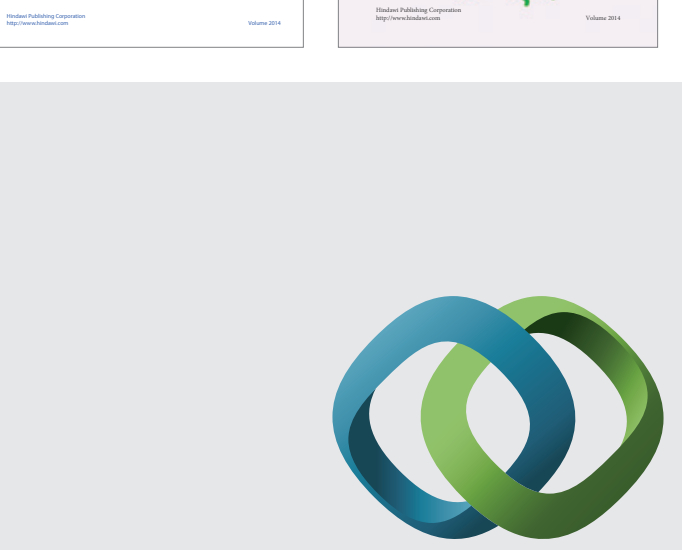

\section{Hindawi}

Submit your manuscripts at

http://www.hindawi.com
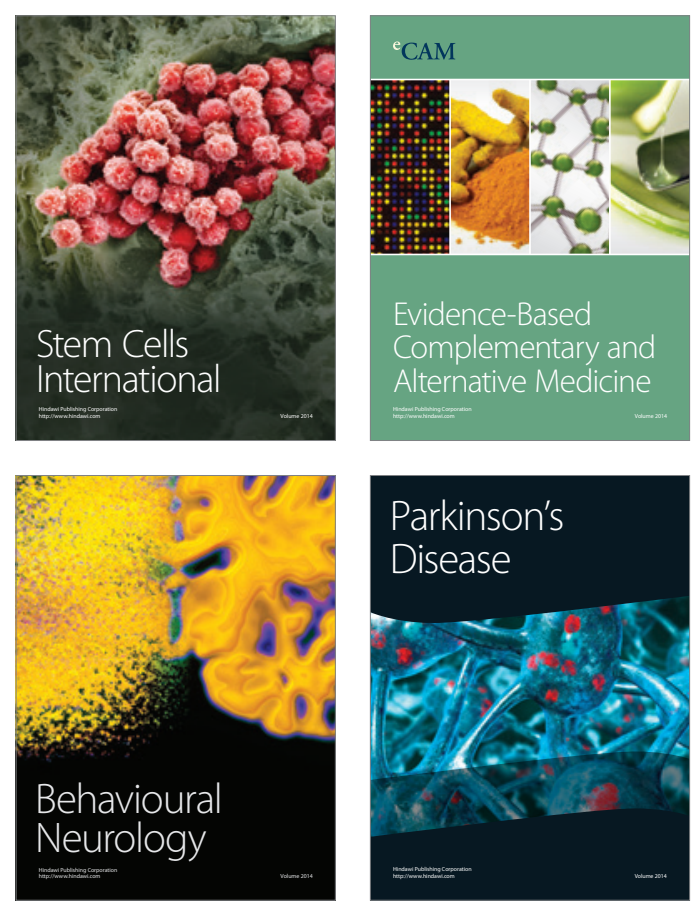

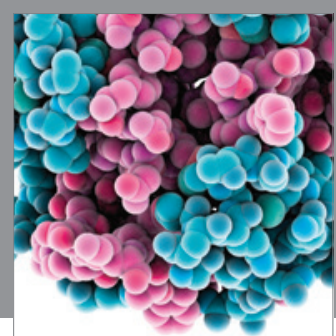

Journal of
Diabetes Research

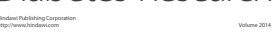

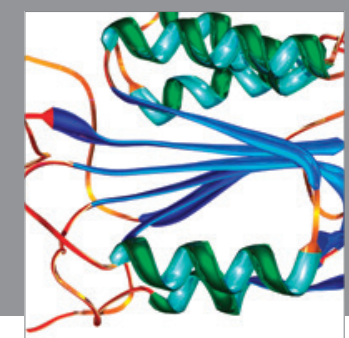

Disease Markers
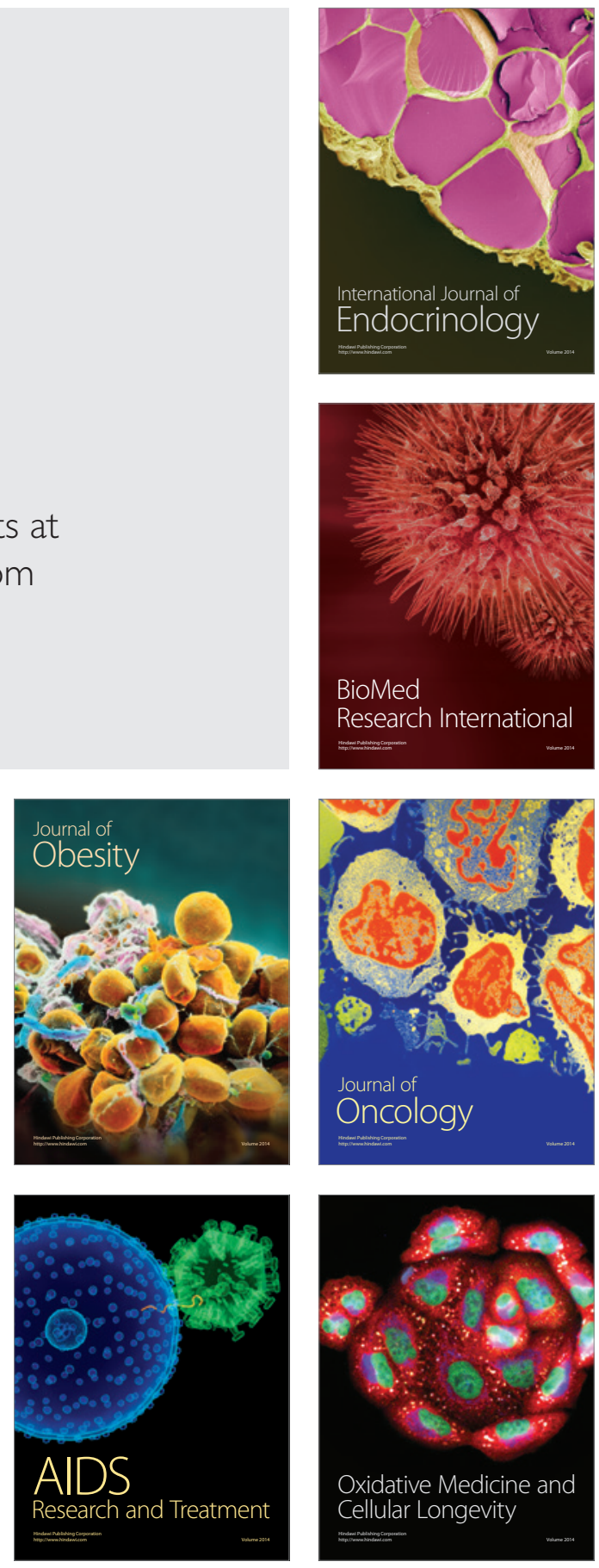